\title{
LIFE AND WORKS OF ABUL HASAN`ALI NADWI (RA): AN ANALYTICAL STUDY
}

\author{
Samee-Ullah Bhat \\ University of Kashmir, \\ Srinagar, Jammu and Kashmir
}

\begin{abstract}
Maulana Sayyid Abul Hasan Ali Nadwi (Ali Miyan) had an outstanding position, not only in India but also in the Islamic world particularly, in the Arab world. Maulana Ali Miyan was a great socio-religious reformer of the $20^{\text {th }}$ century. His long intellectual and political career, which had influenced the entire Muslim world, deserves special consideration. It is, therefore, worthwhile to be acquainted with his extensive works on vast range of subject, many of which were reliable diagnosis of the multifarious problems the Ummah was facing, and is still facing. His writings which are almost 50 in number revive the faith in the hearts of the millions of the Muslims. In this research paper, an attempt has been made to highlight his prominent contributions to Islamic History and Historiography.
\end{abstract}

Keywords: Seerat-i-Sayyid Ahmad Shaheed, Indian Muslims, Karvaan-i-Zindagi, Nuqoosh-i Iqbal, Saviors of Islamic spirit

\section{Introduction}

Several factors distinguished Maulana Sayyid Abul Hasan 'Ali Nadwi from his contemporaries besides his educational attainments. His lineage goes back to the Prophet Muhammad $(S A W)$ and is hailed for being a part of scholarly family. As both of these traits were rare privileges in combination with scholarship and conveyed an aura of respect and veneration among scholars wherever he travelled. He was indisputably one of the greatest exponents of Islam in the second half of the twentieth century. Due to his command over Arabic, in writings and speeches, he had a wide area of influence extending far beyond the Sub-continent, particularly in the Arab World. His teachings covered the entire spectrum of the collective existence of the Muslim Indians as a living community in the national and international context. For decades, he enjoyed universal respect, was accepted by the non-Muslims, at the highest level, as the legitimate spokesman for the concerns and aspirations of the entire Muslim community. He began his academic career in 1934 as a teacher in Nadwa, later in 1961; he became Principal of Nadwa and in 1980, he was appointed as Chairman of Islamic Centre Oxford, UK. He was a prolific writer in Urdu and Arabic, and his books are part of syllabic studies in various Arab Universities. Several of his works have since been translated into Arabic, English, Turkish, Bhasha Indonesia, Persian, Tamil and some other languages. He is a thinker and author of

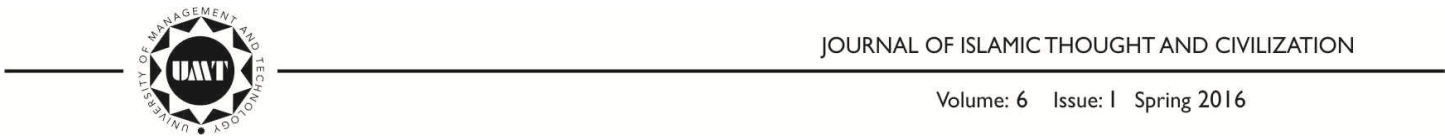




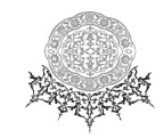

over fifty books in various languages. Internationally recognized, he was one of the Founding Members of the Rabita at-Alam-al-Islami, Makkah, (1963), and served on the Higher Council of the Islamic University, Medina, the Executive Committee of the Federation of Islamic Universities, Rabat, and as the Chairman of the Board for the Centre of Islamic Studies of the Oxford University. The lectures he delivered at Indian, Arab and western Universities have been highly appreciated as original contribution to the study of Islam and on Islam's relevance to the modern age. In 1980, he received the Faisal International Award, followed by the Brunei Award and the UAE Award in 1999. The numerous awards and honours conferred upon him bear testimony to his widely-acclaimed literary prowess and contributions to the Islamic cause. His long intellectual and political career, which had influenced the entire Muslim world, deserves special consideration. It is, therefore, worthwhile to be acquainted with his extensive works on vast range of subject, many of which were reliable diagnosis of the multifarious problems the Ummah was facing, and is still facing. It constitutes another reason why he is considered to be a towering intellectual figure of the 20th century.

\section{Abul Hasan Ali Nadwi's Genealogy (1914-1999)}

Abul Hasan Ali Nadwi's genealogy could be traced from Nadwi himself ${ }^{1}$ and goes backwards starting from `Ali Ibn Abi Talib. It is as follows: Ash-Shaikh Abul Hasan Ali Al-Hasani Al-Nadwi bin Allama Abdul Hayy al-Hasani. His lineage joins to AlHasan bin Al-Hussain bin Jahfar bin Al-Qasim bin Al-Hasan Al-Jawwad bin Mohammed bin Abdullah Al-Ashar bin Muhammed Zinnafs Azzakiyya bin Abdullah Mahl bin Al-Hasan Al-Musanna bin Al-Imam Al-Hasan bin Al-Imam Ali bin Abi Talib (RA).

According to Historians Amir Qutb-ud-deen is counted as the first migrant (1185-1278) from Arab Island to India. He is the paternal grandfather of Abul Hasan Ali Nadwi.

\subsection{Early Life and Intellectual Milieu}

Sayyid Abul Hasan 'Ali Nadwi was born in the Takiya Kalaan Rae-Bareilly in North India in 1914 and passed away on Friday 23rd December, 1999 at the age of 86. In the principality of (Utrapradesh) in India on 23rd October 1914, he was named Ali and his full name is Ali bin Abdul Hay bin Fahruddeen Al-Hasani. His linage joins to Imam Al-Hasan bin Sabt bin Ali bin Abi Talib. ${ }^{2}$

Scion of a well-educated and pious family, which has produced scholars, Ulama, Atkiya, spiritual preceptors, mujahedeen, professors, civil service officers, he

\footnotetext{
${ }^{1}$ Abul Hasan Ali Nadwi, Al-Murtaza (Damascus: Darul Qalam 1989), 20.

${ }^{2}$ Muhammed al-Majzoob, Ulama wal Mufakkiruna Araftuhum (Ulama of our Age) (Jeddah: Aalam al-Ma'rifah Li al-nashriwal thawzi,1983),135.
}

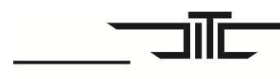

JOURNAL OF ISLAMIC THOUGHT AND CIVILIZATION 
was an eminent scholar, thinker, writer, an enlightened Alim, an eloquent preacher, a wise genius reformer and most outstanding personality of the world of Islam in the last half century.

His father was Abdul Hayy Hasani, author of famous books like Nuzhatul Khawatir (a biographical dictionary of Indian Ulama) and Al-Thaqafah al-Islamiyah fil-Hind (Islamic Culture in India). He was a descendant of Sayyid Ahmad Shaheed who had led a Jihad movement against the British occupation, established an Islamic state in the North Western Frontier (now in Pakistan) and fell martyr on the battlefield of Balakot in 1831. Moreover, he was one of the few non-Arabs today who had fully mastered spoken and written Arabic. Although he is an Arab by lineage, yet his family had lost its roots with the Arabic world and he grew up as an Indian Muslim. He was popularly known in India as Ali Miyan. His genealogical epithet was Hasan, as he came from the prominent Sayyid family of the Ashraf - the local Muslim notables, who claimed origins from outside the Indian subcontinent, and among them the Sayyids were recognized to be especially privileged for their roots of kinship with prophet Muhammad $(S A W)$. However, he was popularly known world-wide by the name of Nadwi, which was not his family name; it was synonymous to higher rank of Islamic intellectuals belonged to a particular institution: the scholars educated at the prestigious Nadwat-ul-ulama in (Lucknow), India, took the name 'Nadwi' and the name 'Nadwi' in this research refers to Abul Hasan Ali Nadwi.

Nadwi grew up and was guided in a peaceful and God fearing environment in the guardianship of his family. His father Maulana Hakim Syed Abdul Hayy Nadwi al-Hasani was an accomplished Islamic scholar in his own right and had written many books, one of which, Nuzhat al-Khawatir- monumental biographical dictionary of the Indian 'ulama in Arabic language is very famous and consists of eight volumes. He served as Rector of Nadwat-ul-ulama until he breathed his last on Friday 1923 when Abul Hasan Ali Nadwi was only nine years of age. Having lost his father, young Ali grew up under the shadow of his pious mother and the guardianship of his beloved brother, Dr. Hakim Abdul Ali Nadwi (who qualified from both Dar al-Ulum Deoband and Nadwat-ul-ulama). He lived in his early childhood in Takiyya Kalan; RaeBareilly. He later migrated to Lucknow with his father because of his father's profession as a doctor. His pious mother had memorized the Holy Qur'ān by heart and acquired higher education, a rare distinction for a woman of her times. She was a poet as well as a writer. She wrote the book for the guidance of women and young girls with the name of 'Husnul Maashirah' (Social Manners) and the book of poems by the name of 'Bahrurrahmah.' She sacrificed all her efforts for his education and upbringing, encouraging him on performing his duties, respecting the elders and being kind to the youngsters and performing the prayers on time. She always used to supplicate the (Dua) following prayer for him,

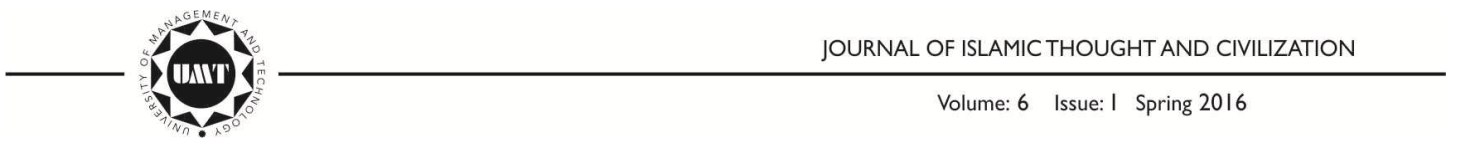


Oh Allah $(S W T)$ ! Because of your grace my son Ali came into existence in the world and he cannot live without your sustentation and protection. Enlighten him! Bless him to glow in the world with the wisdom you have bestowed to him to become instrumental in making the Islamic universe and the world as a whole brighter! Let the world be impregnate and be benefitted by him. Oh Allah (SWT) accept my prayer, respond to my plea and bless Ali with a life full of happiness, pride, privilege and luck. ${ }^{3}$

When Ali was young he spent most of his time in his elder brother's house, under his supervision and tender care. A particularly important influence on him at this stage was his elder brother, Sayyid Abd al-Ali al Hasani who later went on to be trained as a medical doctor at King George's Medical College, Lucknow, and then assumed the post of Rector of the Nadwat-ul-'Ulama. His elder brother was able, through his deep knowledge both in western education and Islam, to ensure his upbringing in the Islamic way of life. By this time he had developed a deep commitment to the cause of Islam.

This privileged setting helped him immensely to grow up as a genius with a pristine blend of a number of qualities and characteristics. His thoughts ahead of his time, his maturity and noble qualities could be traced to his early life and the excellent upbringing he had. ${ }^{4}$

\subsection{Intellectual Milieu}

In order to be trained as an Alim (religious scholar), he was sent to Nadwat-ululama for higher studies. Nadwat al-ulama also known as Nadwa, the choice of the name got inspiration from a hall in Makkah, where nobles used to assemble to debate and discuss. It was one of the renowned Islamic universities in the world, which has produced several famous scholars. It was founded in 1894 at Kanpur and eventually shifted to Lucknow (India) in 1898. It was established with the objective of countering the challenges of western education; striking out equilibrium between classical Islam and modernity and producing a new breed of Islamic scholars of higher level, molded in classical Islamic disciplines and new ideas to regain the intellectual initiative lost in the wake of colonial occupation. At Nadwa, young Nadwi was exposed to new trends prevalent in Islamic thoughts in other Muslim countries. He was also benefitted from the two leading Arab teachers at Dar al ulum. One of those teachers is Khalil Muhammad of Yemen and Taqiuddin al-Hilali of Morocco who taught him modern verbal and written Arabic. He studied Hadith under Sheikh Husain Ahmed Madani at Dar al-ulum, Deoband and Tafsir under Maulana Ahmad Ali of Lahore where he came in touch with Iqbal whose poetry left an abiding impression on him.

\footnotetext{
${ }^{3}$ Mohamed Ijtibaun Nadwi, Abul Hasan 'Ali al-Hasan al-Nadwi, Addaieyat al-hakim wal Murabbil Jalil (Damascus: Darin Qalam), 29.

${ }^{4}$ Ibid., 29-33.
}

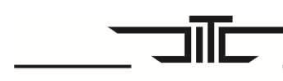

JOURNAL OF ISLAMIC THOUGHT AND CIVILIZATION 
The major turning point in Nadwi's life came in 1934, when he was appointed to teach Arabic and Qur'ānic commentary at Nadwat al-ulama, after the completion of his studies. The Nadwa committed itself to spread the teachings of Nadwi since he played a pivotal role in turning the institution into well acknowledged research center world widely, just as he was to remain central to the life of the institution, turning it into a widely recognized centre for Islamic research. As Hasan writes, one of his principle concerns as head of the institution was to promote suitable changes in the educational system in accordance with the demand of the modem age. 5

\subsection{Works of Nadwi}

Maulana Nadwi had a unique style of writing history, which bear distinct historical roots and reflect an in-depth study of the subject of Islamic history. May it be the penning of a biography or a thesis recounting the rise and expansion of Muslim power; or lamentations on civilizational maladjustment following the diminishing fortunes of Muslims in India; or the obligations to pay literary tribute to the spiritual orders, Maulana Nadwi derives an inherent satisfaction in heaping himself with the debris of history. He delves into it and digs with the spirit of a research scholar and spade, until convincing proof is forthcoming to clear the haze on views taken for granted and to report on events of history hitherto ignored by the historians at large. The Prominent works of Nadwi can be well discussed as under:

\subsubsection{Seerat-i-Sayyid Ahmad Shaheed (Biography of Sayyid Ahmad Shaheed)}

Maulana Nadwi's first literary endeavor and debut as a historian was his historical biography entitled, Sayyid Ahmad Shaheed written in 1938-39 C.E. Earlier he had also published an article on "Sayyid" in reputed Arabic Journal Al-Manar of Syed Rashid Reda during A.H. 1349-50 (1931 C.E). The book Sirat-i-Sayyid Ahmad Shaheed is a memoir of life, works and achievements of the founder of the greatest revivalist movement known to Indian history. It is the comprehensive, wellresearched and painstakingly portrayed, documenting the vast material existing on the subject. The author claims, "Fortunately, I have also had the advantage of having access to certain original sources, not available to others, and also the opportunity to study the life and mission of Sayyid Ahmad Shaheed from close quarters. I had, therefore, been giving thought to the matter from comparatively early age and also written a monograph on the subject.",

Therefore, utilizing all existing sources on the subject to produce a worthy work to understand the real worth and value of Sayyid Ahmad Shaheed's movement

\footnotetext{
${ }^{5}$ Mohamed Tariq Zubaidi, Sirat, Samahat al-Shaikh Abil Hasan al-Nadwi, Al-Shaikh Abul Hasan al-Nadwi," (A Biography of Abul Ali Hasan Nadwi) A Research and Study, Muslim World League, Al-Risala (Beirut: 2002): 535.

${ }^{6}$ Sayyid Abul Hasan Ali Nadwi, A Misunderstood Reformer, trans. Mohiuddin Ahmad (Islamic Research and Publication, Lucknow, 1978-79), 6.
}

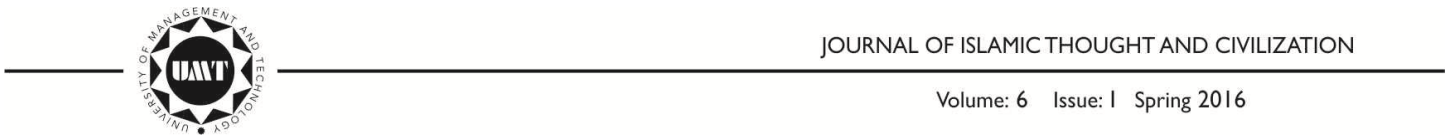




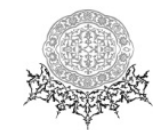

and the place he occupied among the luminaries of Islam. The book made an instant success and received wide acclaim, both within and abroad. It was written originally in Arabic, then Urdu. The way this book was received was an indication of the popularity of Sayyid Ahmad Shaheed and the urge of the people to know more about him. Political situation prevailing in India then had created an upsurge in the Muslims, who were eager to reclaim their identity and to see Islam strong and powerful in the world. Naturally, the Sayyid Ahmad's message of hope and faith, of self-confidence and self-realization, contained in the book, was enthusiastically welcomed by them. ${ }^{7}$

Maulana Nadwi's book and other related writing on Sayyid Ahmad Shaheed, in addition, proved to be a refutation and cleared many misconceptions about Sayyid Ahmad and his movement disseminated by some western writers, such as P. Hardy, The Muslims of British India. W. W. Hunter, Indian Musalmans and some apologetic writers. As Nadwi claims:

I drew attention to and protested against the biased and extremely intolerant attitude of the western writers, in regard to the Sayyid Ahmad and his mission. I tried to show that dearth of material was not the cause of their partisan and unwarranted observation, as it so often happens in depicting the true character and achievements of the reformers of the old. For, in such cases, the writers usually exercise their whimsical speculations to present a character sketch. ${ }^{8}$

But according to Maulana Nadwi, it seems that the chroniclers never wanted to ascertain true facts; they gave credence to every groundless rumour without evaluating the relative evidential value of the report reaching them. Therefore, on their part it was sheer shadow of narrow-spiritual charitableness bequeathed by the crusades, which was not expected of the present age persons professing to be rationalists. ${ }^{9}$

\subsubsection{Hindustani Musalman (Indian Muslims)}

Maulana Nadwi's another important book on history, which deserves special mention, is Hindustani Musalman, originally delivered in Arabic and afterwards translated into Urdu and later into English as Muslims in India. The role of Islam and Muslims in the history of India has been deliberately distorted, first by western writers, to serve their vested interests in India; by the socialist and secular historian blinded by ideological baggage, Hindu extremist writers because of their jaundiced views about it and as well by the Muslims apologetic writers. As, Maulana Nadwi himself writes:

\footnotetext{
${ }^{7}$ Ibid., 40.

${ }^{8}$ Ibid., 7.

${ }^{9}$ Ibid.,35.
}

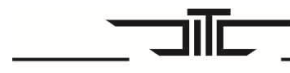

JOURNAL OF ISLAMIC THOUGHT AND CIVILIZATION 
The tragedy, however, is not confined only to ignorance what is worse and more disconcerting is that there has got created in our country a powerful tendency to blackout and reject the history and the cultural stock of a whole community, its past achievements and the glorious contribution it has made to the national fight for independence. There is a foot campaign to present the history of our land in a manner as if the Muslim era in India was an era of foreign, imperialistic domination; it was devoid of all virtue and greatness and failed miserably to produce a single noteworthy personality, a single remarkable achievement in the domains of thought and culture, a single act of unpolluted, selfless service to the country's welfare and development of which the nation could be proud, and that in the long-drawn battle for freedom against the British, the Muslims were nothing more than disinterested spectators, and if they did, accidentally, take part, it was not worthy of attention... Though it is entirely in opposition to what history tells. ${ }^{10}$

To dispel misconception created by some misinformation about the role of Muslims in India, Maulana Nadwi's book may be considered as the most useful publication on the subject, which has given an apt respond to those historians, who consider the period of Islamic dominations as a dark age in the history of this subcontinent. Published in 1953C.E. when Muslims in India were in desperate search for such objective writing, projected the real image with accuracy to ward off senseless onslaughts on their identity and existence in their very homeland. This comprehensive but a brief book is highly useful because it is not possible for all to read other voluminous work in Persian and even in Urdu of the old style to enquire into the manifold cultural, literacy, material, and political achievements of Muslim period in Indian history. Therefore, this book of Maulana Nadwi gives detailed exposition of Muslim genuineness that has gone into the making of Indian history and culture. Their presence at every form of life throughout the most important period of Indian history drew out the best in them, laying the foundation of a broad-based and composite culture. The contribution of Muslims at all levels of life and society left its multi-dimensional impression on almost all human activity, including statecraft and land management. He demonstrated the role played by the Muslims in the progress and development of the motherland, the achievements of Muslim scholars and their contribution and role of Muslims in the freedom struggle of India. In the words of Maulana Nadwi,

They gave India and Indian civilization a new lease of life and a new dimension and awakened its people to a new set of moral and spiritual values. Every path of its land and every particle of its soil bear the imprint of their greatness and is a monument of its industry, earnestness and creative genius. In every aspect of Indian life and civilization can be seen evidences of their noble aestheticism and cultural richness. ${ }^{11}$

\footnotetext{
${ }^{10}$ Sayyid Abul Hasan Ali Nadwi, Muslims in India (Lucknow: Islamic Research and
} Publication, 1980), 2-4.

${ }^{11}$ Ibid., 5.

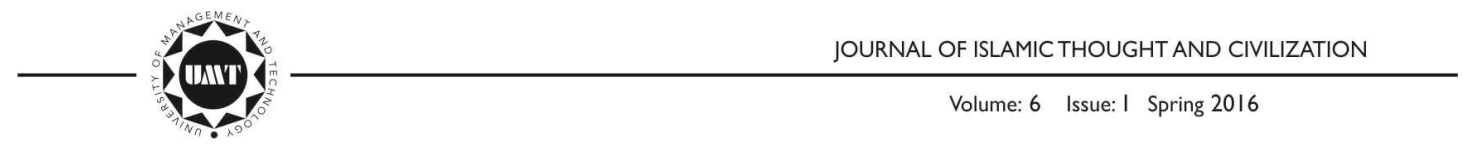




\subsubsection{Karvaan-i-Zindagi (Caravan of Life)}

Karvaan-i-Zindagi ${ }^{12}$ is a voluminous autobiography of Maulana Nadwi in eight volumes which is a profound contribution to the history as well as to Urdu literature. Originally, the book was written in Urdu. In this work, Maulana Nadwi tried to cover all the information related to himself as well as the remarkable events of his life. Maulana Nadwi's motivation for writing his autobiography is not merely to recount memorable milestones in his life but to provide an all-encompassing spectrum of his activities that delineates his intellectual growth and development. The historical incidents in his life are contextualized to provide the reader an opportunity to examine his role in the said events, in which Maulana Nadwi was an active participant. Furthermore, his autobiography makes copious reference to his prolific writings to highlight his contribution to contemporary Islamic thought. The Karvaan-i-Zindagi also attempts to explore Maulana Nadwi's vision and thought regarding Islam and humanity as well as what was his attitude for the renaissance of Islam in the modern age. Maulana Nadwi stated in his autobiography that, he believed in steadfastness, progress, to make use of everything old which is beneficial, welcomed everything new which is sound, adopted from tradition what is sincere and rejected what is dubious. Karvaan-i-Zindagi represents his synopsis of his other important works, which analyzed for a more complete appreciation of his contribution to contemporary Islamic thought.

\subsubsection{Nuqoosh-i Iqbal (Glory of Iqbal)}

Nuqoosh-i Iqbal (Glory of Iqbal) ${ }^{13}$ is among the most famous work of Maulana Nadwi, well accepted across the Muslim world, particularly in India and Arab world. The strength of his work lies in inspiring the Muslims by reminding them of their glorious past. To Maulana Nadwi, Iqbal - the greatest Muslim poetphilosopher of the Indian subcontinent- was a phenomenal personality who endowed with profound spiritual power, a keen sense of attachment to the Ummah of Islam, as well as a comprehensive knowledge of western philosophical and economic systems. His poetry awakened the Muslims of India who make up a significant ration of the Muslim world, both in numbers as well as in terms of civilizational and scholarly contribution to Islam. The author traces the greatness of Iqbal and his message through his texts, and enumerates six such factors and apparent forms of his life and poetry. First, it is Iqbal's faith in Islam, which grew stronger as he matured and studied the Eastern western philosophies. Iqbal was an immensely learned man, and a few modern Muslim intellectuals can boast to be equal to Iqbal in their knowledge of the west and its philosophical foundations. Iqbal's faith also grew stronger as he

\footnotetext{
${ }^{12}$ Sayyid Abul Hasan Ali Nadwi, Karvaan-i-Zindagi, Vol.3 (Lucknow: Maktabae Islam, n.d.).

${ }^{13}$ Sayyid Abul Hasan Ali Nadwi, Nuqoosh-i Iqbal (Lucknow, Academy of Islamic Research and Publication, 2006), 73-74.
}

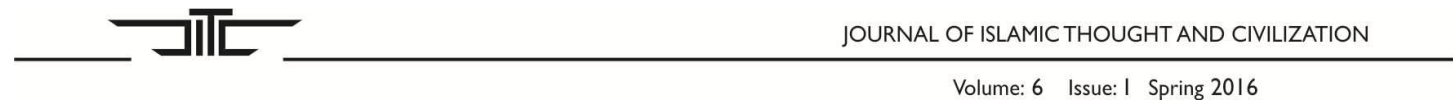


toured Europe and obtained his degrees in philosophy, economics, and law. Secondly, the author showed Iqbal's attachment to Qur'ān. The secret of Iqbal's sound Qur'ānic knowledge was that he would read the Qur'ān with such concentration and attention that it appeared as if it were being revealed to him there and then. Thirdly, Iqbal's strength came from his paramount emphasis on, Khudi (Selfhood). He sought to know himself, and prescribed the same path for all Muslims, to develop a strong sense of Selfhood (confidence in oneself) through reliance on Allah (SWT) alone. The fourth aspect was Iqbal's strictly followed routine of contemplation, worship and recitation in the early hours of the day. The fifth and last source of Iqbal's fountain of aspiration was the great Persian scholar, the famed poet of Mathnawi, Jalaluddin Rumi. Iqbal sought to speak against materialism and atheist philosophy like Rumi had once fought the ill effects of Greek philosophy on the Muslim world. The author then went on to explore the major themes that underline the great poet-philosopher's works. Iqbal viewed the European civilization with the eye of a keen observer and came to despise it. Iqbal predicted that the western civilization will commit suicide, and will vanish shortly, for it has disconnected itself from the inner world of the soul and spirituality and had become excessively engrossed with materialism.

\subsubsection{Tarikh-i Dawat Wa Azimat (Saviours of Islamic Spirit)}

Maulana Nadwi's personality and vision seemed largely defined by his six volume magnum opus, Tarikh-i Dawat Wa Azimat, translated into English as Saviours of Islamic Spirit (4 vols.). In these volumes, he has extensively portrayed the intellectual and religious efforts of Islam, its social history and revivalist and reformative endeavors and has introduced in a copious way the leaders of such movements. He had categorically stated in the introduction of the book that in Islam there has been a continuity of reformative movements and there were no long interregnums of suspense or in action. Tarikh-i Dawat wa Azimat answers the key questions in Islamic history. Viz, what's there in Islamic society which, despite all the vicissitudes and debacles, explains its undiminished resilience? The Islamic history is a history of dawah and fortitude and which keeps on refusing and reviving itself through Tajdid, Islah and Jihad.

Tarikh-i Dawat Wa Azimat provides an alternative view of looking at Islamic history as a history of 'Ulama and intellectuals instead of a chronicle of Sultans and regimes some noble and horrible. Depending upon their respective circumstances some of the 'Ulama took part in or even led Jihad, others concentrating on winning the hearts and soul of the people. Not surprisingly Islamic society has suffered more by the decline of the 'Ulama than the disloyalty of its Umara (rich and power people). ${ }^{14}$

\footnotetext{
${ }^{14}$ M. H. Faruqi: "Abul Hasan Ali Nadwi," in Impact International, reproduced by The Fragrance of East, January-June, (2000): 130.
}

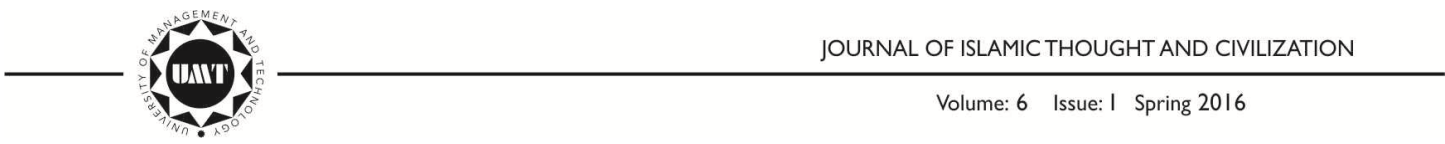




\subsubsection{Madha Khasir al-Alam bi Inhitatil Muslimeen (Islam and the World)}

Much acclaimed book of Maulana Nadwi is Madha Khasir al-Alam bi Inhitatil Muslimeen (Islam and the World) for which he received accolades throughout, especially Arab world where it was first published in 1951 C.E, with a foreword by the leading modernist writer Ahmad Amin. However, many who read the book, including King Abdullah-I of Jordan, felt that Ahmad Amin's foreword lacked a fuller understanding of the book's driving theme. The second and subsequent editions of the book carried a new foreword, this one by Sayyid Qutb. The book was later translated into English under the title of Islam and the World and into Urdu, Persian and Turkish.

This book critically analyzed the rise and fall of Muslims and its impacts thereafter. The author's main contribution however, is the appreciation of Muslim rulers of the Arab world and their rise to power, their enthusiasm towards Islam; contribution towards human civilization and their zeal for the promotion of Islam. After the glorious period of Islam, the author highlighted the decadence of Muslim power because of their luxurious life and they lost original fervor to Islam, due to which later Muslim rulers became the victim of their enemies and succumbed to their ensued downfall. This book is considered by Von Grunebaum, as a representative self-review of contemporary Islam. The book is an analysis of history from the Age of Ignorance (Jahiliyah Period) of Arabia to the Modern age. Firstly, the author presents a picture of moral degradation of societies before the advent of Islam, their political, social, economic, and moral deterioration. He particularly discusses the societies of the Roman and Persian Empires, Arabs, Christians and Jews etc.

The age before Islam was an age, steeped in ignorance, in which the mind and the spirit of man had become deteriorated and high standards of morals and values of life had become debased. Sayyid Qutb of Egypt has stated in his foreword, "What was the condition of the world before the advent of Islam and the state of affairs in the east and the west, the north, and the south? What was the intellectual temper of man from China to India, and from Persia to Rome? What was the color and texture of contemporary societies? In what state were those Faiths of the world, which based on heavenly sanctions like Judaism and Christianity, and those, that worship idols and fire like Hinduism and Paganism? The questions with which the book actually starts, dealt with in a concise and comprehensive manner. The figure that the book presents of that age is clear-cut and delineates its features with accuracy and insight. There was not a single man and movement of reformation that exists in the whole world. Even the religious sections in various societies like priests and rabbis; have introduced unrecognized activities and rituals in their religion for the sake of their materialistic interests." In the words of Maulana Nadwi, "the previous faiths became play things in the hands of debased ecclesiastics who corrupted and twisted them

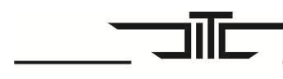

JOURNAL OF ISLAMIC THOUGHT AND CIVILIZATION

Volume: 6 Issue: I Spring 2016 
beyond recognition, so much so that if it were possible for their founders to return to physical life, they could not have to recognize them."

The book in its style and treatment does not however, ponder to mere sentiments or excite passions of dogmation. The claims that it makes are sustained by solid scholarship and objective research in a manner that appeals both to the mind and heart. The enlightened and unprejudiced mind of the author is clearly revealed by the scrupulous care and deep concern from truth with which historical events and their sequences are recorded and environmental effects and ramifications analyzed. Decisions are left to the discernment of enlightened minds and a conscience that is sensitive to truth. Topics have been discussed, arranged and interfered in such a manner that no conclusion is ever forced on the reader. ${ }^{16}$

After describing the age of ignorance (Jahiliyah), in its salient feature, the author has outlined the part played by Islam in the reconstruction of humanity. Delineates upon the role of Islam in saving the human society from decadence and degeneration, in liberating the soul of man from superstitious and banalities, emancipated him from the evils of slavery and degradation, and liberated man from the tyranny of kings and the dominance of priests. It struck a harmonious balance between the world of faith and world of action, therefore Islam never proved to be barrier to progress and science. It was Islam that made earlier Muslims great but later generations got deviated from the teachings of Islam resulting in the decline of Muslim fortunes. The author describes succinctly the reasons for the material and spiritual decay in the Muslims and points out that the harm the Muslims suffered was due to digression from the principle of their faith and turning away from the responsibilities it entailed.

Thus according to Maulana Nadwi, with the failure of the Muslims to sustain and discharge efficiently the great responsibility of trusteeship of mankind which Islam enjoined upon them, Islam lost its world leadership. Paving the way for west to take the leadership of the world, which is sheer materialism? Therefore, ignorance, which prevailed before Islam, reigned again in the presence of western civilization. Then he, explains the cruel and catastrophic consequences of the transfer of worldleadership from the Muslims to the western people, whose appetites are purely material and who have, thereof, built-up a structure which is utterly inimical to the needs of human mind and spirit. Maulana Nadwi has objectively delineated on the subject of western civilization and its impact also in his another book translated into English under the title of Western Civilization Islam and Muslims.

${ }^{15}$ Sayyid Abul Hasan Ali Nadwi, Islam and the World (Lucknow, Academy of Islamic Research and Publication, 1981),181.

${ }^{16}$ Sayyid Qutub, in Foreword to Nadwi's Islam and the World, 2.

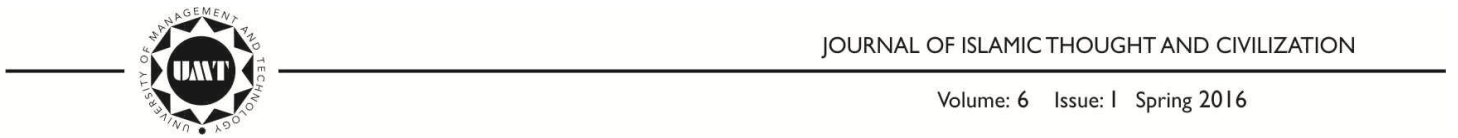


Maulana Nadwi through this book Madha Khasir al-Alambi Inhitatil Muslimeen re-instills hope of revival of Islam in the seat of world leadership. In the words of Sayyid Qutb:

The Historical analysis of Maulana Nadwi's writings makes one to strongly believe that the time has come when the present leadership should be changed to restore humanity from darkness to light and from ignorance to knowledge and wisdom..The reader of the book soon realizes how much important such a guidance is to the world today and what a terrible loss humanity has suffered in losing it. This loss is not faced by the Muslims only but is shared by the whole world ... and carelessness, he also becomes acutely aware of the tremendous potentialities, that have been given to him and begins to feel an overpowering urge to regain the world leadership he lost through his own neglect and lack of appreciation of its quality. ${ }^{17}$

\section{Conclusion}

In this research article, an attempt has been made to highlight the contribution of one of the great luminaries of the twentieth century in Islamic history and historiography who stood for social reform, religious revival, political awakening and for revolution through the medium of Islamic history. The historical analysis of Maulana Nadwi makes one to believe strongly that the time has come when the present leadership should be changed to restore humanity from darkness to light and from ignorance to knowledge and wisdom.

\footnotetext{
${ }^{17}$ Ibid., 4.
} 


\section{BIBLIOGRAPHY}

Ali Nadwi, Abul Hasan. Al- Murtaza. Damascus: Darul Qalam 1989.

- Nuqoosh-i Iqbal. Lucknow, Academy of Islamic Research and Publication, 2006.

- A Misunderstood Reformer. Translated by Mohiuddin Ahmad. Islamic Research and Publication, Lucknow, 1978-79.

- . Islam and the World. Lucknow, Academy of Islamic Research and Publication, 1981.

-. Karvaan-i-Zindagi (Caravan of Life, URDU) Vol.3, Lucknow: Maktabae Islam.

—. Muslims in India. Lucknow: Islamic Research and Publication, 1980.

al-Majzoob, Mohammed. Ulama wal Mufakkiruna 'Araftuhum. Jeddah: Aalam alMa'rifah, Li al-nashriwal thawzi,1983.

Faruqi, M. H. “Abul Hasan Ali Nadwi." in Impact International, reproduced by The Fragrance of East, January-June, (2000)

Nadwi, Mohamed Ijtibaun. Abul Hasan 'Ali al-Hasan al-Nadwi, addaieyat alhakim wal murabbil Jalil. Damascus: Darin Qalam.

Zubaidi, Mohamed Tariq. Sirat, Samahat al-Shaikh Abil Hasan al-Nadwi, AlShaikh Abul Hasan al- Nadwi." A Research and Study, Muslim World League, Al-Risala. Beirut: 2002.

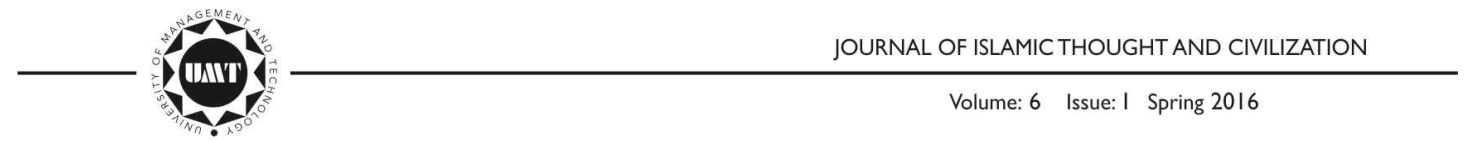


